\title{
Microstructure and Properties of 3D Printed Inconel 718 Joint Brazed with BNi-2 Amorphous Filler Metal
}

\author{
Chunzhi Xia ${ }^{a,{ }^{*}}{ }^{\mathbb{C}}$, Meng Zhao ${ }^{a}$, Weiwei Sun ${ }^{a}$, Huaixue Lit, Peng Liu \\ ${ }^{a}$ School of Materials Science and Engineering, Jiangsu University of Science and Technology, \\ Zhenjiang, P.R. China \\ ${ }^{b}$ AVIC Beijing Aeronautical Manufacturing Technology Research Institute, Beijing, P.R. China \\ ${ }^{c}$ School of Materials Science and Engineering, Shandong Jianzhu University, Jinan, P.R. China
}

Received: May 16, 2018; Revised: September 19, 2018; Accepted: October 19, 2018

\begin{abstract}
Three dimensional (3D) printing technology has been widely used in metal manufacturing industry. This study focused on the vacuum brazing of 3D printed Inconel 718 superalloy with BNi-2 amorphous filler metal. Interfacial microstructure and element distribution revealed excellent wettability and spreadability of the filler metal as well as favorable brazability of the base material. Brazed joint could be divided into two distinct zones: isothermally solidified zone (ISZ) consisting of $\gamma$-Ni solid solution and diffusion-affected zone (DAZ) consisting of a large amount of precipitates besides $\gamma$-Ni solid solution. Microhardness reached peak values in DAZ. Although borides filled the gaps of base material's grains to restrict grain boundary sliding and restrain the expansion of gaps, but its high hardness and brittleness would cause DAZ turn into weaker region when external loads were very large. The complete diffusion of $\mathrm{B}$ indicated the completion of isothermally solidified process. Precipitate $\mathrm{CrB}_{2}$ with high hardness and brittleness was the key point of reducing the joint strength. Shear strength of the brazed joint was up to $802 \mathrm{MPa}$, and fracture morphology presented a mixed ductile-brittle fracture.
\end{abstract}

Keywords: Vacuum brazing, 3D printed Inconel 718 superalloy, isothermal solidification, shear strength, mixed ductile-brittle fracture.

\section{Introduction}

Inconel 718 alloy, a precipitation-strengthened Ni-based superalloy, possessed a series of outstanding properties such as corrosion and creep resistance, high tensile and yield strength, favorable plasticity and service life and so on ${ }^{1,2}$. Turbo vane, axle, strutting piece, fastener and other essential parts in modern aeroengine were made by Inconel 718 alloy. Besides, Inconel 718 alloy also applied as pivotal parts in aerospace, nuclear power, oil exploitation and other fields ${ }^{3}$. The fabrication of Inconel 718 alloy generally forged again after casts blank with purpose of improving properties ${ }^{4-6}$. In addition, Inconel 718 had stable atomic structure and numerous hard-nodal compounds, which caused difficult machining and serious tool wear ${ }^{7}$. As a result, Inconel 718 had high fabricating cost and could not be directly fabricated into complex parts ${ }^{8,9}$.

In the process of transformation of fabricating mode, 3D printing technology has achieved extensive attention ${ }^{10}$. Based on the concept of calculus, 3D printing technology allows to fabricate more uniform and refined microstructure, for that $3 \mathrm{D}$ printing technology maybe a potential candidate to replace conventional fabricating mode ${ }^{11-14}$. In addition, 3D printing technology can make the structure of parts no longer restricted as well as apply to the repair of damaged parts, which has turned out to be a significant savings ${ }^{15,16}$.

*e-mail: cz xia@126.com
Even though 3D printing equipments have improved a lot, however, dimensions of the forming parts still could not meet the demands on larger parts ${ }^{17}$. Under these circumstances, traditional welding process has attracted much attention to overcome this problem by joining two or more 3D printed parts to form larger final parts with no dimensions limitation ${ }^{18,19}$.

In the work by Hanchen Yu et al., laser welding was successfully used to join selective laser melted (SLMed, one commonly used method of 3D printing technology) to SLMed and SLMed to wrought Ti-6Al-4V specimens, showing that stress-relieved SLMed Ti-6Al-4V alloy had a good laser weldability ${ }^{20}$. Prashanth also studied the welding of SLMed Ti-6Al-4V and Al-12Si, but he used friction welding method. Results showed that solid-state processes like friction welding could be successfully used to join SLMed materials and might also be beneficial for improving the ductility at only a marginal decrease in strength ${ }^{21,22}$. Casalino et al. used laser-arc hybrid welding to join wrought to SLMed AISI $316 \mathrm{~L}$ stainless steel, showing the flexibility to form large components by welding ${ }^{23}$. In addition, Nahmany et al. used electron beam welding to join AlSi10Mg produced by SLM additive manufacturing technology workpieces successfully ${ }^{24}$.

In this study, brazing method with small deformation of substrates and excellent formation on the bonding interface was used to braze SLMed Inconel 718 with BNi-2 amorphous filler metal ${ }^{25-27}$. The interfacial microstructure, element distribution, phase constituent, shear strength, and fracture 
morphology of the brazed joint were analyzed by means of scanning electron microscope (SEM), X-ray diffraction (XRD), energy dispersive spectrum (EDS) and transmission electron microscope (TEM) $)^{28}$. The results would provide a favorable basis for further studies on the joining of 3D printed alloy and for application of compound structures.

\section{Materials and Experiment Procedures}

\subsection{SLM process and properties of SLMed inconel 718 alloy.}

Spherical gas-atomized Inconel 718 alloy powder was used in this study with a mean particle size of $45 \sim 65 \mu \mathrm{m}$. The SLM equipment was developed independently by the Aviation Industry Corporation of China (AVIC) Beijing Aeronautical Manufacturing Technology Research Institute and consisted mainly of an IPG fiber laser with a spot diameter of 60 200 $\mu \mathrm{m}$ and a wavelength of approximately $1050 \mathrm{~nm}$ in continuous mode, galvanometer scanning system (the maximum scanning speed was up to $7000 \mathrm{~mm} / \mathrm{s}$ ), an automatic and precise powder layering device (thickness of a single layer was $20 \sim 100 \mu \mathrm{m}$ ), a gas protection system and a computer system for process control. A stainless steel substrate plate was horizontally fixed on the building platform during the whole SLM process with dimensions of $350 \mathrm{~mm} \times 350 \mathrm{~mm}$ $\times 30 \mathrm{~mm}$. Before SLM process, alloy powder needed to be dried and substrate plate needed to be wiped with acetone. Single melt continuous style used in this fabricating process was that all the hatches were oriented parallel to each other and they were continuous, as shown in Figure 1. Based on some previous researches and several attempts, laser power and scanning speed were set at $350 \mathrm{~W}$ and $700 \mathrm{~mm} / \mathrm{s}$ respectively, layer thickness and hatch distance were set at $0.06 \mathrm{~mm}$ and $0.1 \mathrm{~mm}$ respectively ${ }^{29-33}$. In addition, Ar was used as the protective gas in the SLM process ${ }^{34}$.

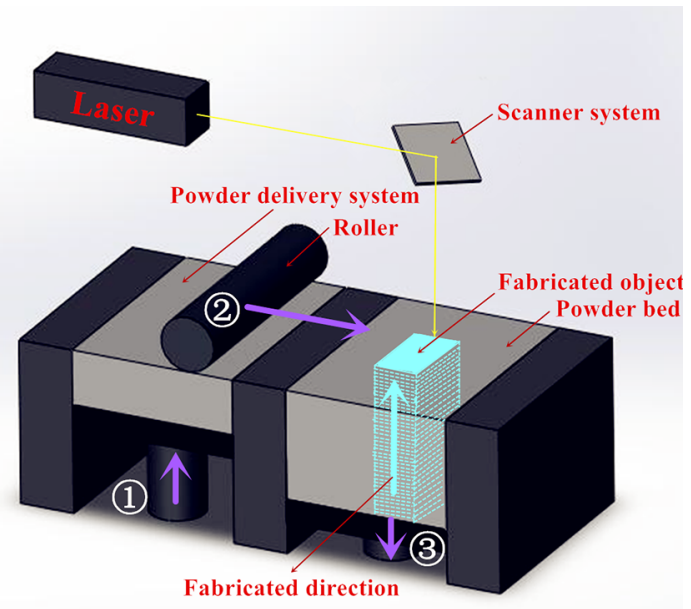

Figure 1. Fabricating schematic of the base material.
After been etched by a mixed solution of $\mathrm{HCl}, \mathrm{CH}_{3} \mathrm{CH}_{2} \mathrm{OH}$ and $\mathrm{CuCl}_{2}(100 \mathrm{~mL}: 100 \mathrm{~mL}: 5 \mathrm{~g})$, microstructure of the base material was studied by super depth of field microscope. Shoot location and metallurgical structure were shown in Figure 2. As could be seen from the figure, each layer could be easily observed and refine grains distributed evenly and densely, which accounted for high density of the base material ${ }^{34-37}$.

XRD curve of the base material was shown in Figure 3. It showed that the matrix phase of the base material was $\gamma$-phase, which was improved by means of lattice distortion. The typical second-phase strengthening such as $\mathrm{Ni}_{3}(\mathrm{Al}, \mathrm{Ti}, \mathrm{Nb})$ $\left(\gamma^{\prime}\right)$ and $\mathrm{Cr}-\mathrm{Ni}-\mathrm{Fe}-\mathrm{C}$ (carbide) could be found from the XRD curve. Second-phase strengthening was the key point for the base material to obtain favorable comprehensive performance. Moreover, the precipitation rate of $\mathrm{Ni}_{3} \mathrm{Nb}(\gamma$ ") was too slow to precipitate from $\gamma$-phases for that $\mathrm{Ni}_{3} \mathrm{Nb}$ could not be found in the XRD curve ${ }^{38}$.

\subsection{Characteristics of the BNi-2 amorphous filler metal}

During rapid cooling process, melts are too late to crystallize and remain the cohesive form of unordered atomic arrangement under the conditions of normal or lower temperature, which is called amorphous phase ${ }^{39}$. At present, amorphous alloys are primarily used to fabricate

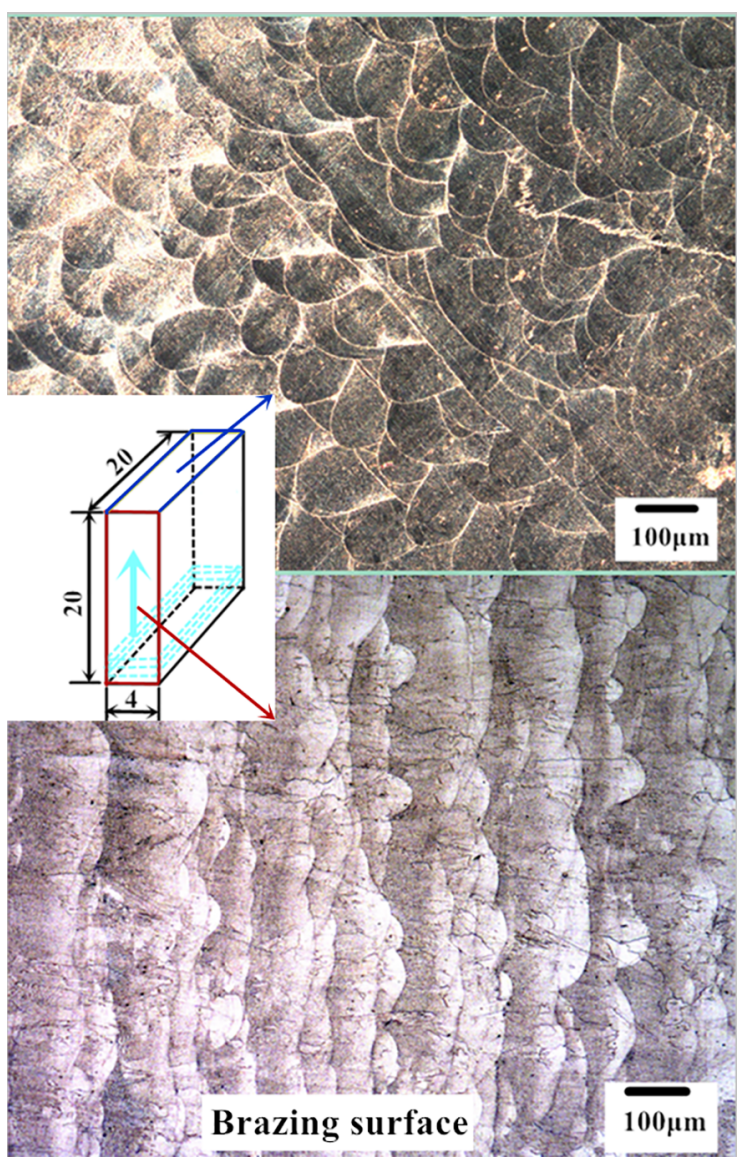

Figure 2. Microstructure of the base material. 


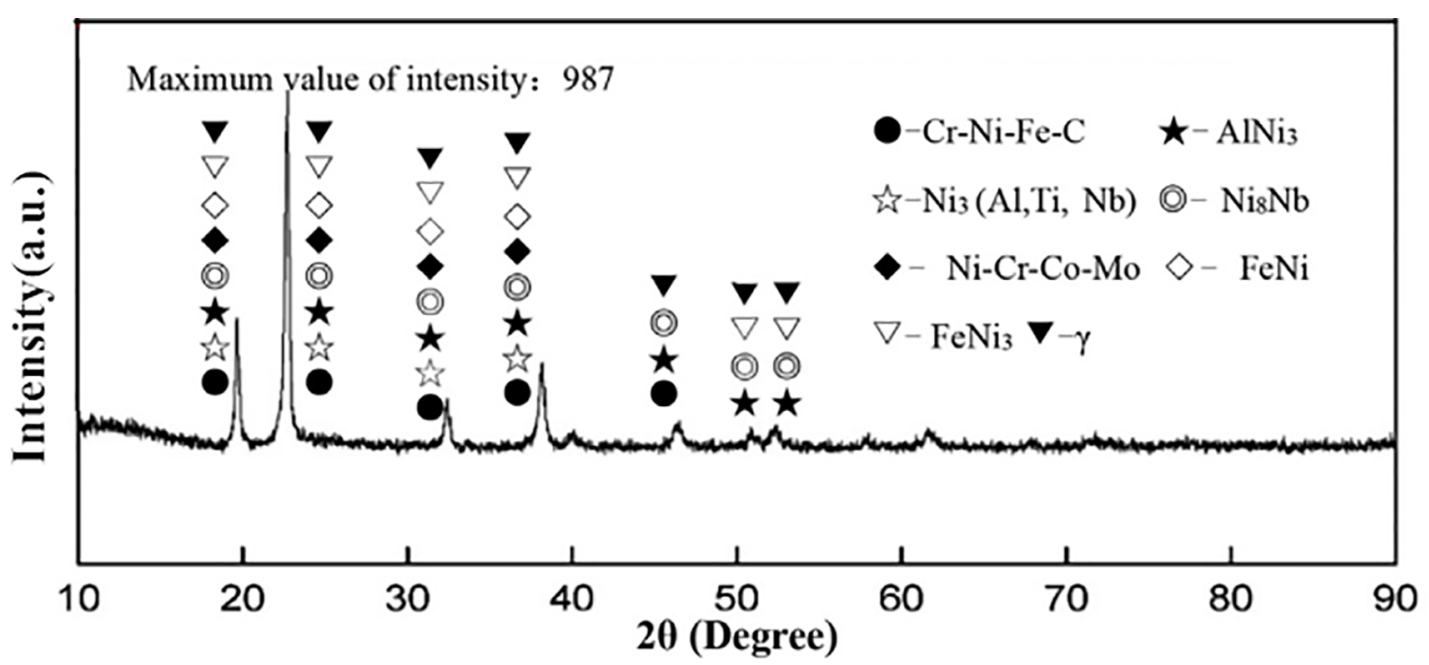

Figure 3. XRD curve of the base material before brazing process.

amorphous filler metal with purpose of avoiding the grain coarsening and composition segregation of crystalline filler metal. By rapid cooling technology, amorphous filler metal could be fabricated into foils, so that they could be used as a preplaced preform ${ }^{40,41}$. Especially for the joints with small clearance, amorphous filler metal could be applied in an accurate and minimal amount. Amorphous filler metal also featured in homogeneous chemistry, strong ability of spreading and wetting, narrow melting temperature range and instantaneous melting and so on ${ }^{42}$. What's more, amorphous filler metal could decrease the brazing temperature, which could reduce residual stress developed in the joint and then increase the joint strength.

For brazing Ni-based alloys, Ni-Cr-B-Si systems filler metals were commonly considered as the best choice due to its good compatibility with the base material and the resultant high mechanical properties and corrosion resistance of the joints. During cooling process, the primary phase with same composition of the base material was easy to grow up at the interface of base material, forming a firm metallurgical bond with base material, which would be beneficial to improve the joint strength ${ }^{43,44}$. Thus, BNi-2 amorphous filler metal with low melting temperature was perfectly suitable for the brazing of Ni-based alloys.

The roles of the elements played in $\mathrm{BNi}-2$ amorphous filler metal might be summed up about like this: Cr could enhance the antioxidant ability of the filler metal; non-metallic elements Si and B were melting point depressant elements as well as the main elements to form brittle phases. However, $\mathrm{B}$ and $\mathrm{Si}$ also could improve wear ability of the joint due to its high hardness.

\subsection{Brazing sample preparation and brazing process}

3D printed Inconel 718 base material was cut by a linear cutting machine into blocks with dimensions of 20 $\mathrm{mm} \times 20 \mathrm{~mm} \times 4 \mathrm{~mm}$; BNi-2 amorphous filler metal was prepared in form of foil with a thickness of $60 \mu \mathrm{m}$, and cut into rectangular shape with dimensions of $20 \mathrm{~mm} \times 6 \mathrm{~mm}$. The nominal chemical compositions of the base material and filler metal were given in Table 1.

Before being brazed, the oxidation film and greasy dirt on the surface of the base material and filler metal were eliminated by emery papers, and then cleaned by ultrasonication in alcohol for $15 \mathrm{~min}$. After cleaning process, brazing samples were assembled in a special clamp. Moreover, a $50 \mathrm{KPa}$ pressure was imposed on the surface of upper base material, with purpose of promoting the filler metal to spread out and wet adequately on the base material. Then, the clamp and the samples were placed together into a KJL-2 vacuum furnace for brazing under the process parameters of vacuum level superior to $6 \times 10^{-3} \mathrm{~Pa}$, brazing temperature at $1060^{\circ} \mathrm{C}$ and holding time for $30 \mathrm{~min}$.

After brazing process, samples were cut by a linear cutting machine into blocks with dimensions of $40 \mathrm{~mm} \times 3 \mathrm{~mm} \times 4$ $\mathrm{mm}$. Then, they were ground with a series of different types of emery papers, polished, and finally etched with a mixed solution of $\mathrm{HCl}, \mathrm{CH}_{3} \mathrm{CH}_{2} \mathrm{OH}$ and $\mathrm{CuCl}_{2}(100 \mathrm{~mL}: 100 \mathrm{~mL}$ : $5 \mathrm{~g})$ for about 30 seconds.

\subsection{Structural and compositional analysis}

Scanning electron microscopy (SEM, model JSM-6408) was used to observe the microstructure of the brazed joint and the fracture surface. Energy dispersive spectroscopy (EDS, model INCA) coupled to the X-ray diffraction (XRD, model 6000), was performed to determine the element distribution and phase composition of the brazed joint. Moreover, transmission electron microscopy (TEM, model JEM-2100F) was applied to accurate judgment of the phase constituent in DAZ. Nano indentation (model NHT2+MST) was also conducted to compare the microhardness variation between ISZ and DAZ. 
Table 1. Elements constituent of base material and filler metal (wt.\%)

\begin{tabular}{lccccccccccc}
\hline \multicolumn{10}{c}{ Chemical compositions (wt.\%) } \\
\hline & $\mathbf{N i}$ & $\mathbf{C r}$ & $\mathbf{F e}$ & $\mathbf{S i}$ & $\mathbf{B}$ & $\mathbf{N b}$ & $\mathbf{M o}$ & $\mathbf{C u}$ & $\mathbf{M n}$ & $\mathbf{A l}$ & $\mathbf{T i}$ \\
\hline $\begin{array}{l}\text { Base } \\
\text { material }\end{array}$ & 54 & 20 & $\mathrm{Bal}$ & 0.3 & - & 4.9 & 3.1 & 0.5 & 0.2 & 0.6 & 0.9 \\
Filler metal & $\mathrm{Bal}$ & $6-8$ & $2.5-3.5$ & $4-5$ & $2.75-3.5$ & - & - & - & - & - & - \\
\hline
\end{tabular}

\subsection{Mechanical properties}

The mechanical properties of the brazed joints were evaluated by room temperature shear strength. The test samples were cut into blocks of $40 \mathrm{~mm} \times 6 \mathrm{~mm} \times 5 \mathrm{~mm}$ and tested on an electronic mechanical testing machine (model CMT5205) using a special fixture with a cross-head speed of $0.5 \mathrm{~mm} / \mathrm{min}$. From the load-displacement curve, the maximum strength $(\sigma)$ was calculated using the following equation:

$$
\sigma=\frac{F}{b h}
$$

In the equation, $F$ is the load at the maximum displacement, and $b(\mathrm{~mm})$ and $h(\mathrm{~mm})$ are the width and thickness of samples, respectively.

\section{Results and Discussion}

\subsection{Microstructure and microhardness of interface zone}

Figure 4 showed the typical interfacial microstructure of the SLMed Inconel 718 brazed joint. It could be seen from Figure 4 that a smooth and clear joint interface without solidified defects such as microcracks and pores was formed, which attributed to excellent wettability and spreadability of filler metal and favorable brazability of base material. Brazing seam with width about $50 \mu \mathrm{m}$ entirely consisted of solid solution, which one illustrated the completion of isothermally solidified process, another, it appeared perfect dissolution and diffusion between base material and filler metal. The solid solution reaction of between $\mathrm{Ni}$ from base material and $\mathrm{Cr}$ and $\mathrm{Si}$ from filler metal was the reason for the emergence of the diffusion layer, which improved the bonding strength of the joint. Preservating heat for a period of time at brazing temperature, concentration difference caused by interdiffusion between base material and filler metal was a major driving force of isothermal solidification. Under this driving force, $\mathrm{B}$ and $\mathrm{Si}$, which were easy to form brittle compounds, diffused into base material and avoided forming brittle compounds in brazing seam centre. On both sides of the brazing seam, plenty of unordered precipitates could be easily observed, with the dimensions gradually growing bigger from brazing seam to base material.

Figure 5 showed the microhardness variation between ISZ and DAZ. In ISZ, the microhardness leveled off, which confirmed that isothermally solidified process had completed and formed uniform solid solution in ISZ. However, in DAZ, there was several microhardness reaching peak values. It could be preliminary concluded that DAZ precipitated some borides with higher microhardness value.
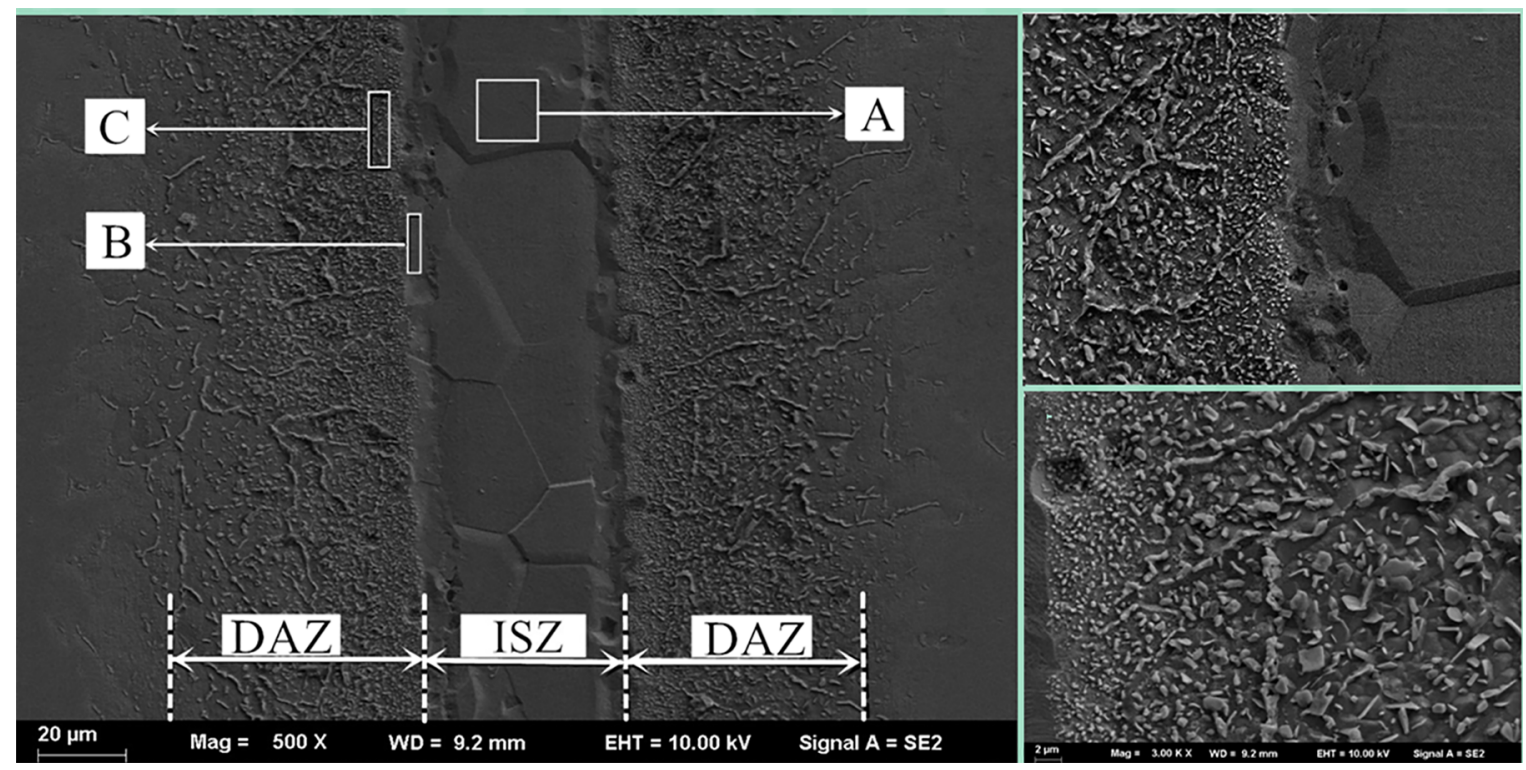

Figure 4. SEM microstructure of the brazed joint. 


\subsection{Element distribution by EDS}

Depending on different microstructural feature, three typical feature regions were selected to analyze the element constituent, as marked in Figure 4. EDS analysis results of $\mathrm{A}, \mathrm{B}$ and $\mathrm{C}$ regions were shown in Table 2. It was important to note that the EDS analyzer was insensitive to light element B, due to that the content and distribution of $B$ could not be detected. In brazing seam region (region A), the content of $\mathrm{Ni}$ was up to $81.71 \%$, together with a small amount of $\mathrm{Fe}, \mathrm{Cr}$ and $\mathrm{Si}$. Likewise, the edge of the brazing seam (region B) was similar to brazing seam region in the aspect of element constituent. It could be preliminarily judged that brazing seam consisted of $\gamma$-Ni solid solution, which dissolved a certain amount of $\mathrm{Cr}$, Fe and $\mathrm{Si}$. Due to the small dimensions of a single precipitate in DAZ, EDS analyzer could not measure the accurate element constituent of a single precipitate. The content of $\mathrm{Ni}$ in DAZ (region C) reduced to $47.85 \%$, on the contrary, the content of $\mathrm{Cr}$, $\mathrm{Fe}$, $\mathrm{Nb}$ and Mo had distinct increase.

For further analysis of the elements transformation behavior involved in ISZ and DAZ, element distribution was examined by EDS, and results were shown in Figure 6. From the results, we could concluded that $\mathrm{Ni}$ was distributed uniformly in brazing seam region, confirming that isothermally solidified process of brazing seam was adequately completed and Ni-based solid solution were formed. On the edge of brazing seam, there showed an obvious change in the content of $\mathrm{Cr}$. This was due to sufficient diffusion of B from filler metal to base material, which was strongly attractive to $\mathrm{Cr}$. Obvious diffusion of $\mathrm{Fe}$ confirmed the dissolution reaction of the base material. Compared to B, Si showed good solubility in $\mathrm{Ni}, \mathrm{Cr}$ and $\mathrm{Fe}$, and that explained why Si element mostly

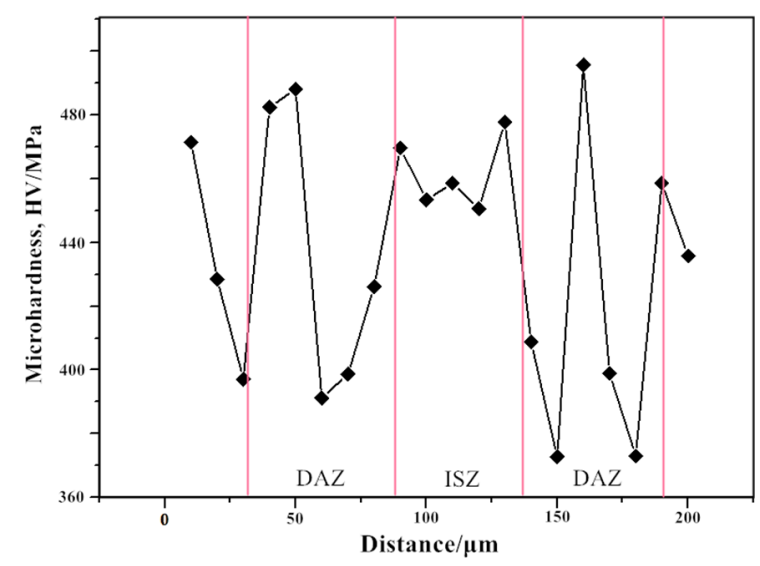

Figure 5. Microhardness variation between ISZ and DAZ. existed in brazing seam region ${ }^{45}$. Mo and $\mathrm{Nb}$ had very high melting point and were hard to melt at brazing temperature so that $\mathrm{Mo}$ and $\mathrm{Nb}$ almost not existed in ISZ.

\subsection{Phase composition by XRD and TEM}

To further clarify the phase constitution near the interface of the brazed joint, the identification of different phases formed was carried out through XRD and TEM analysis, and analysis locations were shown in Figure 7. The obtained results were compared with data from the Joint Committee on Power Diffraction Standards to determine the existing phases.

Figure 8 showed the XRD analysis results of ISZ where entirely consists of $\gamma-\mathrm{Ni}(\mathrm{Cr}, \mathrm{Fe}, \mathrm{Si})$ solid solution. TEM was performed to observe precipitates, and analyze the structure by electron diffraction, as shown in Figure 9. TEM results illustrated that DAZ consisted of matrix $\gamma-\mathrm{Ni}(\mathrm{Cr})$, together with precipitated intermetallic compounds $\mathrm{CrB}_{2}, \mathrm{Ni}_{3} \mathrm{Si}$ and $\mathrm{FeNi}_{3}$. Intermetallic compounds could reduce the plasticity and toughness of DAZ as brittle phases in course of fracture. However, plenty of $\gamma$-Ni solid solution with good plasticity and toughness could ensure favorable mechanical property by overcoming free energy and constraining dislocation stress during brazing process.

\subsection{Mechanical properties by shear test}

\subsubsection{Shear test}

The mechanical property of the brazed joint was evaluated by shear test at room temperature. Three shear test samples were prepared to obtain more accurate shear value. By calculation, the average shear strength of the brazed joint was $802 \mathrm{MPa}$, about $77 \%$ shear strength of the

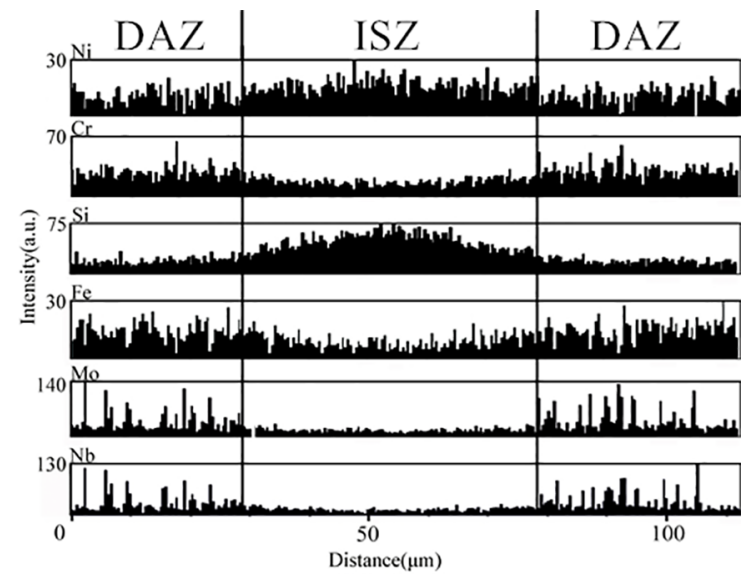

Figure 6. Element distribution of the brazed joint.

Table 2. Elements constituent of different regions (wt.\%)

\begin{tabular}{lccccccc}
\hline Region & $\mathbf{N i}$ & $\mathbf{C r}$ & $\mathbf{F e}$ & $\mathbf{S i}$ & $\mathbf{N b}$ & $\mathbf{M o}$ & $\mathbf{T i}$ \\
\hline A & 81.71 & 6.32 & 8.56 & 3.32 & 0.10 & - & - \\
B & 70.74 & 8.44 & 15.99 & 1.66 & 1.59 & 1.28 & 0.30 \\
C & 47.85 & 18.45 & 18.53 & 1.16 & 7.98 & 5.55 & 0.48 \\
\hline
\end{tabular}




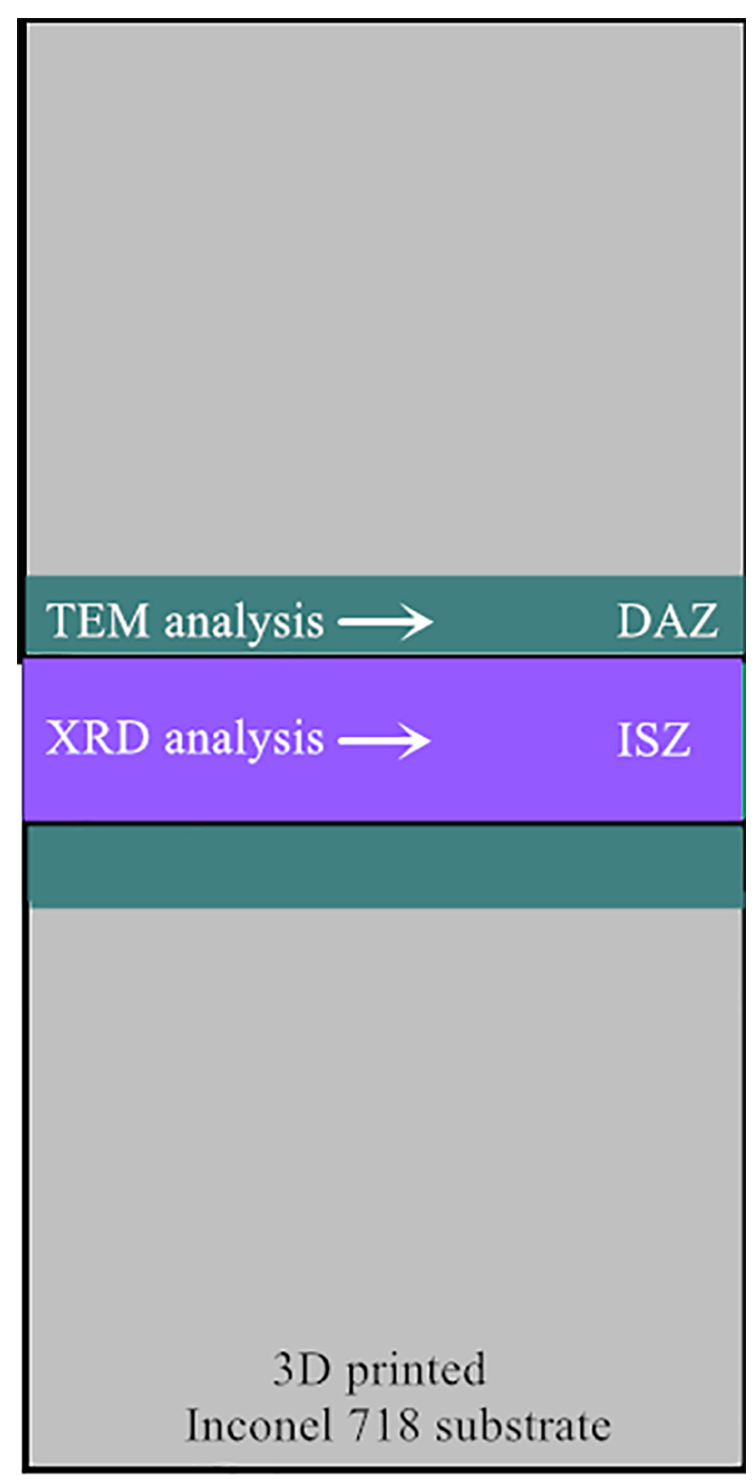

Figure 7. Analysis location of XRD and TEM.

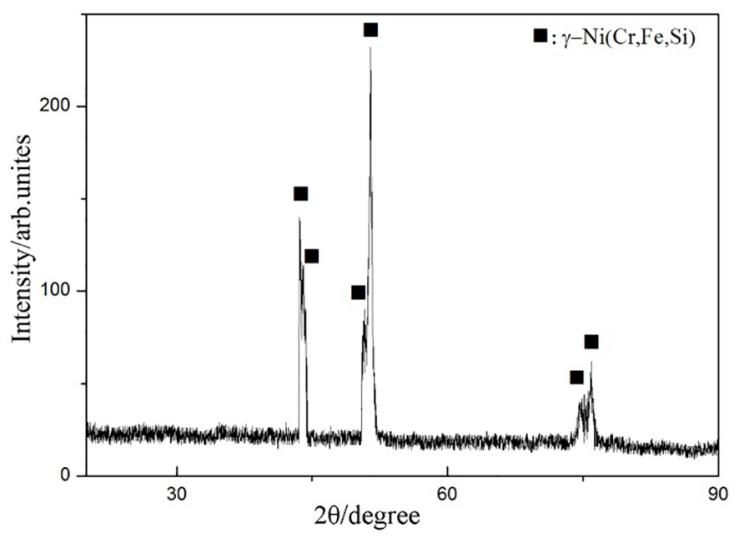

Figure 8. XRD curve of ISZ. base material. Fracture schematic of the brazed joint was shown in Figure 10.

\subsubsection{Fracture feature}

Fracture morphology of the brazed joint was analyzed in order to further explain the high shear strength. It could be observed from Figure 11(a) that the fracture surface was rough and the color was gray. Figure 11(b) showed many dimples with different diameter and obvious river pattern. Dimple was a typical characteristic of ductile fracture, and river pattern represented brittle fracture. The fracture of the brazed joint started from DAZ contained intermetallic compounds, and then penetrated the ISZ and eventually ended up at the other side of the DAZ. Thus, fracture mode of the brazed joint could be judged as a mixed ductile-brittle fracture.

\subsection{Brazing mechanism}

Through above analysis, a clear picture of the brazing mechanism was achieved, as shown in Figure 12. When brazing temperature rose up to the melting point of $\mathrm{BNi}-2$ filler metal, BNi-2 filler metal began to melt and filled gaps through capillary action. Melting point depressant elements $\mathrm{Si}$ and B diffused into substrates while substrates would dissolve slightly into liquid filler metal to achieve a partial balance on the element distribution of solid-liquid interface.

In the stage of heat preservation, with the diffusion of melting point depressant elements $\mathrm{Si}$ and $\mathrm{B}$, element composition of liquid filler metal changed dramatically, which caused liquidus of the filler metal near the base material increased. When the content of $\mathrm{Si}$ and $\mathrm{B}$ reduced to a certain degree (liquidus was higher than brazing temperature), this region began isothermal solidification and nucleated non-uniformly to form $\gamma$-Ni solid solution. The partition coefficient of $\mathrm{Si}$ and $\mathrm{B}$ in Ni-based solid solution was $\mathrm{k}$ $(\sim 0.8)$ and $\mathrm{k}(\sim 0.008)$ respectively, hence Si and B were pushed aside in the process of isothermal solidification. ${ }^{25}$ However, B still could pass through $\gamma$-Ni solid solution to diffuse into base material by virtue of repulsion. Due to that isothermally solidified process could continue and form the relationship of the shift between ISZ and non-isothermally solidified zone. ISZ formed from solid-liquid interface to brazing seam center, and enough holding time ensured the completion of isothermally solidified process.

When holding time was over, $\mathrm{B}$ had already diffused into base material. However, B had strong ability of intergranular permeation, which would cause the decrease of strength and toughness in DAZ. Cr was a strong borides forming element, so $\mathrm{Cr}$ reacted with $\mathrm{B}$ to form $\mathrm{CrB}_{2}$ brittle compounds in DAZ. The borides reduced the content of $\mathrm{Cr}$ in DAZ and then degraded the performance of oxidation and corrosion resistance in this region. But from another perspective, borides acted as a "pinning" effect on the grain boundary of DAZ, which could inhibit grain coarsening. Because the solubility of $\mathrm{Si}$ in $\mathrm{Ni}$ decreased sharply with temperature 

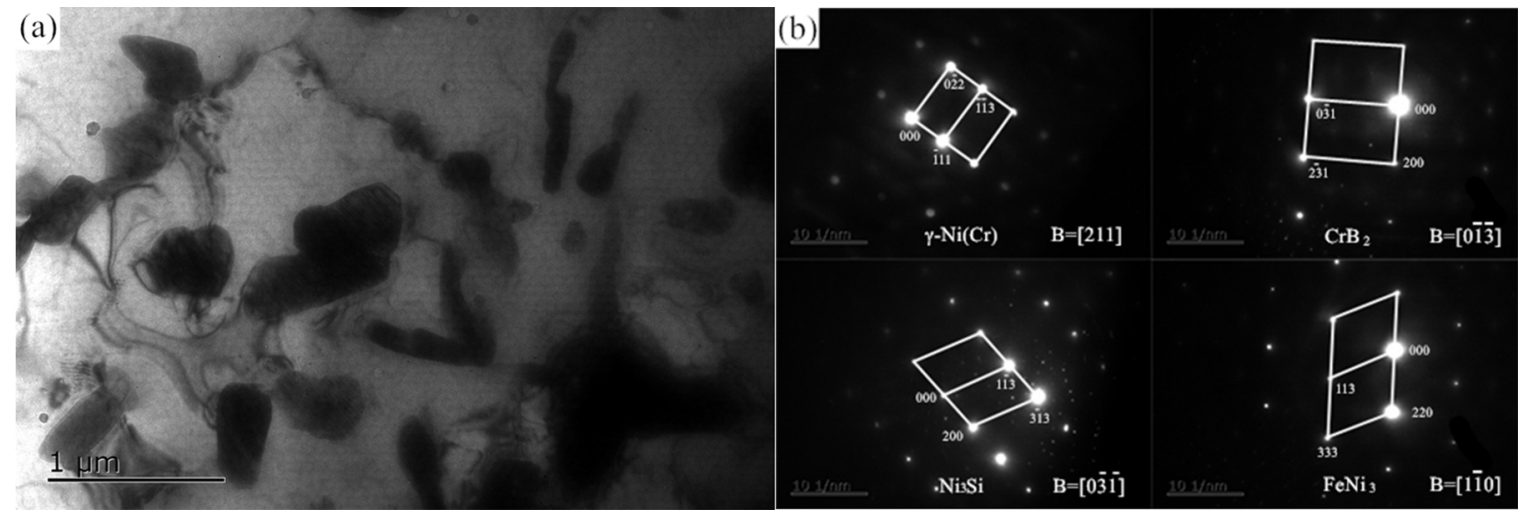

Figure 9. TEM results of DAZ.

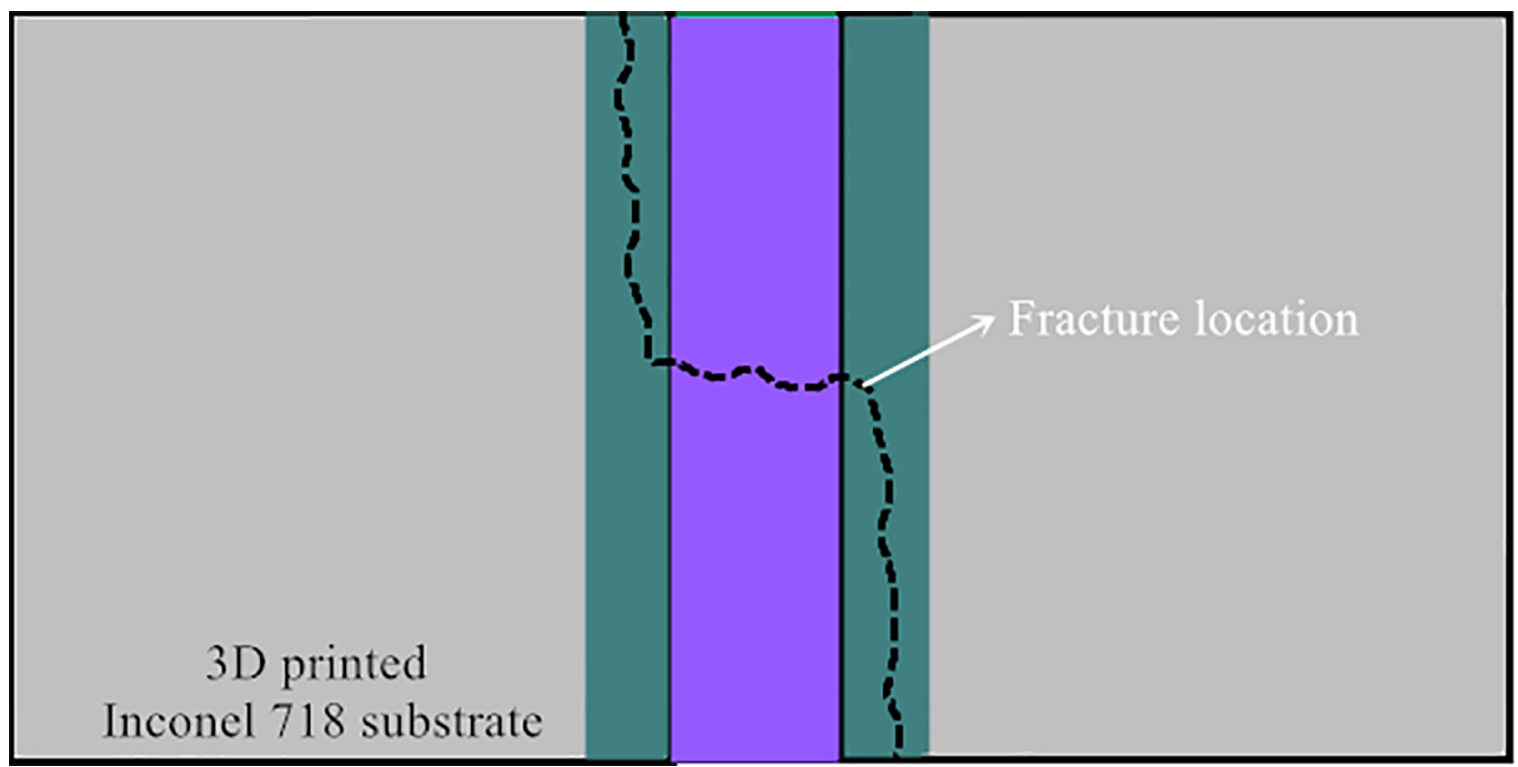

Figure 10. Fracture schematic of the brazed joint.
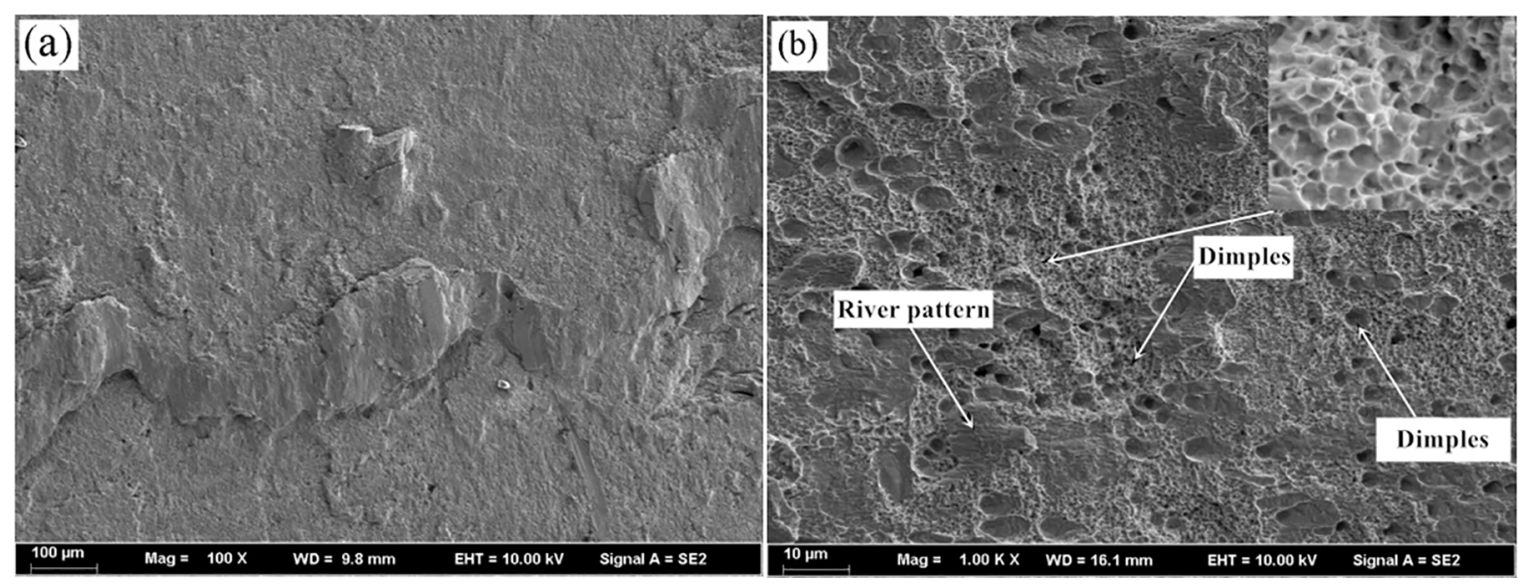

Figure 11. Fracture morphology of the brazed joint.

declined, $\gamma$-Ni solid solution were unable to contain excessive $\mathrm{Si}$, and $\mathrm{Si}$ precipitated in form of $\mathrm{Ni}_{3} \mathrm{Si}$ grains during cooling stage, surrounding $\gamma$-Ni solid solution and playing a role in precipitation strength.
Finally, Brazed joint could be divided into two distinct zones: ISZ and DAZ. ISZ consisted of $\gamma$-Ni solid solution formed by complete isothermal solidification, which were dissolved a large amount of $\mathrm{Cr}, \mathrm{Fe}$ and $\mathrm{Si}$. On the basis of 


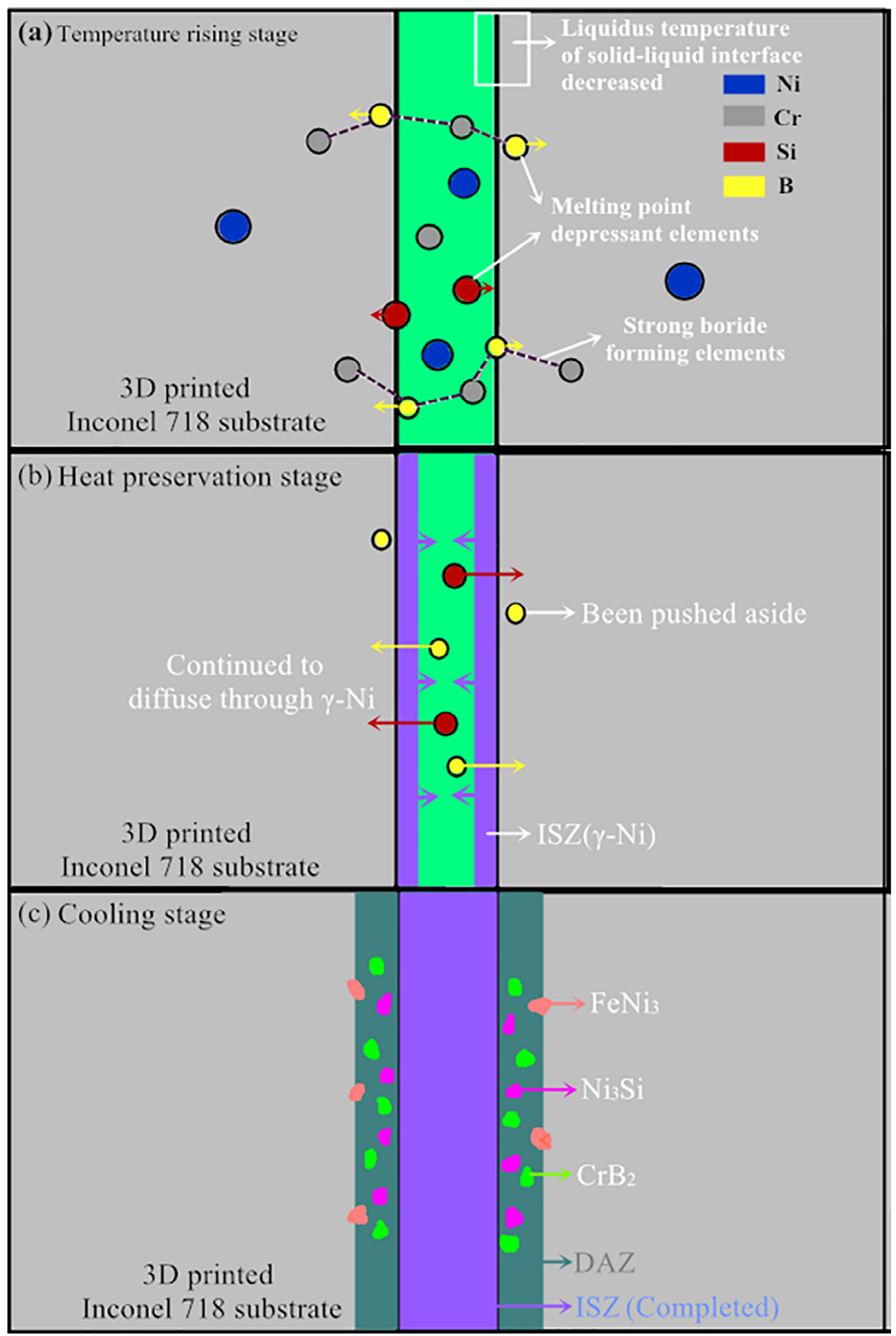

Figure 12. Schematic of the brazing process: (a) Temperature rising stage; (b) Thermal insulation stage; (c) Cooling stage. 
base material, DAZ was influenced by elements diffusion and then generated some borides and silicides at grain boundary.

\section{Conclusion}

1. 3D printed Inconel 718 alloys were successfully brazed with $\mathrm{BNi}-2$ amorphous filler metal in a vacuum furnace with a vacuum level superior to $6 \times 10^{-3} \mathrm{~Pa}$, by controlling the brazing temperature at $1060^{\circ} \mathrm{C}$ and the holding time for 30 minutes. High-magnification SEM showed a smooth joint interface without obvious gas holes, cracks and other microdefects, which meant excellent wettability and spreadability of the filler metal as well as favorable brazability of the base material.

2. The brazed joint consisted of ISZ and DAZ. Microhardness reached peak values in DAZ. The perfect diffusion of B indicated the completion of isothermally solidified process. Another melting point depressant element $\mathrm{Si}$ also had obvious diffusion. The content of $\mathrm{Cr}$ increased gradually from the centre of the brazing seam to both sides of the base material, which was affected by the diffusion of $\mathrm{B}$.

3. XRD analysis of ISZ revealed that the phase existed in ISZ was $\gamma-\mathrm{Ni}(\mathrm{Cr}, \mathrm{Fe}, \mathrm{Si})$ solid solution. TEM analysis of DAZ showed that DAZ consisted of $\gamma-\mathrm{Ni}(\mathrm{Cr})$ solid solution, together with precipitates $\mathrm{FeNi}_{3}, \mathrm{CrB}_{2}$ and $\mathrm{Ni}_{3} \mathrm{Si}$. Borides could reduce the plasticity and toughness of DAZ as brittle phases in course of fracture, but a large number of $\gamma$-Ni solid solution contained in ISZ and DAZ could release the residual stress by overcoming free energy and constraining dislocation stress.

4. Shear value of the brazed joint was up to $802 \mathrm{MPa}$, about $77 \%$ of the base material. Fracture originated at DAZ where a large amount of borides existed. Fracture morphology of the brazed joint was identified as having a mixed characteristic of a brittle fracture of DAZ and a plastic fracture ISZ.

\section{Acknowledgements}

This project was supported by the National Natural Science Foundation of China (grant No. 51405205), the project funded by the China Postdoctoral Science Foundation (No.2015M581751) and Shandong Provincial Natural Science Foundation, China (Grant No. ZR2016JL017).

\section{References}

1. Chamanfar A, Sarrat L, Jahazi M, WeckA, Koul AK. Microstructural characteristics of forged and heat treated Inconel-718 disks. Materials \& Design (1980-2015). 2013;52:791-800.
2. Wan M, Rui MA. Failure Analysis of GH4169 Bolts and Its Process Improvement. Hot Working Technology. 2012;16(2):113118

3. Thomas A, El-Wahabi M, Cabrera JM, Prado JM. High temperature deformation of Inconel 718. Journal of Materials Processing Technology. 2006;177(1-3):469-472.

4. Sun GQ, Wang D, Shang DG. Time-dependent multiaxial fatigue and life prediction for nickel-based GH4169 alloy. Fatigue \& Fracture of Engineering Materials \& Structures. 2013;36(10):1039-1050.

5. Courbon C, Pusavec F, Dumont F, Rech J, Kopac J. Tribological behaviour of Ti6Al4V and Inconel718 under dry and cryogenic conditions-Application to the context of machining with carbide tools. Tribology International. 2013;66(306):72-82.

6. Liu D, Luo ZJ. Mixed Grain Structure of GH4169 Alloy Forgings. Hot Working Technology. 2004;9:3-5.

7. Eng RD, Ryan EJ, Doyle JR. Nickel-base brazing filler metals for aircraft gas turbine application. Weld Journal. 1977;56(10).

8. Slama C, Abdellaoui M. Structural characterization of the aged Inconel 718. Journal of Alloys and Compounds. 2000;306(12):277-284.

9. Kang SH, Deguchi Y, Yamamoto K, Ogi K, Shirai M. Solidification Process and Behavior of Alloying Elements in Ni-Based Superalloy Inconel718. Materials Transactions. 2004;45(8):2728-2733.

10. Herzog D, Seyda V, Wycisk E, Emmelmann C. Additive manufacturing of metals. Acta Materialia. 2016;117:371-392.

11. Santos EC, Shiomi M, Osakada K, Laoui T. Rapid manufacturing of metal components by laser forming. International Journal of Machine Tools and Manufacture. 2006;46(12-13):1459. 1468.

12. Leary M, Mazur M, Elambasseril J, McMillan M, Chirent T, Sun Y, et al. Selective laser melting (SLM) of AlSi12Mg lattice structures. Materials \& Design. 2016;98:344-357.

13. Gu DD, Meiners W, Wissenbach K, Poprawe R. Laser additive manufacturing of metallic components: materials, processes and mechanisms. International Material Reviews. 2013;57(3):133-164.

14. Badrossamay M, Childs THC. Further studies in selective laser melting of stainless and tool steel powders. International Journal of Machine Tools and Manufacture. 2007;47(5):779784.

15. Sufiiarov VS, Popovich AA, Borisov EV, Polozov IA. Selective laser melting of heat-resistant Ni-based alloy. Non-Ferrous Metals. 2015;1(38):32-35.

16. Murr LE, Gaytan SM, Ramirez DA, Martinez E, Hernandez J, Amato KN, et al. Metal Fabrication by Additive Manufacturing Using Laser and Electron Beam Melting Technologies. Journal of Materials Science \& Technology. 2012;28(1):1-14.

17. Zhang B, Liao H, Coddet C. Selective laser melting commercially pure Ti under vacuum. Vacuum. 2013;95:25-29.

18. Chlebus E, Kuznicka B, Kurzynowski T, Dybala B. Microstructure and mechanical behavior of Ti-6Al-7Nb alloy produced by selective laser melting. Materials Characterization. 2011;62(5):488-495. 
19. Li Y, Qian D, Xue JW, Wan JC, Zhang AF, Tamura N, et al. A synchrotron study of defect and strain inhomogeneity in laser-assisted three-dimensionally-printed Ni-based superalloy. Applied Physics Letters. 2015;107(18):181902.

20. Yu H, Li F, Yang J, Shao J, Wang Z, Zeng X. Investigation on laser welding of selective laser melted Ti-6Al-4V parts: Weldability, microstructure and mechanical properties. Materials Science and Engineering: A. 2018;712:20-27.

21. Prashanth KG, Damodaram R, Scudino S, Wang Z, Prasad Rao K, Eckert J. Friction welding of Al-12Si parts produced by selective laser melting. Materials \& Design. 2014;57:632-637.

22. Prashanth KG, Damodaram R, Maity T, Wang P, Eckert J. Friction welding of selective laser melted Ti6A14V parts. Materials Science and Engineering: A. 2017;704:66-71.

23. Casalino G, Campanelli SL, Ludovico AD. Laser-arc hybrid welding of wrought to selective laser molten stainless steel. International Journal of Advanced Manufacturing Technology. 2013;68(1-4):209-216.

24. Nahmany M, Rosenthal I, Benishti I, Frage N, Stern A. Electron beam welding of AlSi10Mg workpieces produced by selected laser melting additive manufacturing technology. Additive Manufacturing. 2015;8:63-70.

25. Arafin MA, Medraj M, Turner DP, Bocher P. Transient liquid phase bonding of Inconel 718 and Inconel 625 with BNi-2: Modeling and experimental investigations. Materials Science \& Engineering: A. 2007;447(1-2):125-133.

26. Ruiz-Vargas J, Siredey-Schwaller N, Gey N, Bocher P, Hazotte A. Microstructure development during isothermal brazing of $\mathrm{Ni} / \mathrm{BNi}-2$ couples. Journal of Materials Processing Technology. 2013;213(1):20-29.

27. Grushko B, Weiss BZ. Structure of Vacuum Brazed BNi-5 Joint of Inconel 718. Metallurgical Transactions A. 1984;15(4):609620 .

28. Zhou Y, Xia CZ, Yang J, Xu XP, Zou JS. Microstructure and properties of $\mathrm{W}-\mathrm{Cu} / 1 \mathrm{Cr} 18 \mathrm{Ni} 9$ steel brazed joint with different Ni-based filler metals. Science \& Engineering of Composite Materials. 2016;25(3):463-472.

29. Zhang YN, Cao X, Wanjara P, Medraj M. Oxide films in laser additive manufactured Inconel 718. Acta Materialia. 2013;61(17):6562-6576.

30. Delgado J, Ciurana J, Rodriguez CA. Influence of process parameters on part quality and mechanical properties for DMLS and SLM with iron-based materials. International Journal of Advanced Manufacturing Technology. 2012;60(5-8):601-610.

31. Mazur M, Leary M, Sun S, Vcelka M, Shidid D, Brandt M. Deformation and failure behaviour of Ti-6Al-4V lattice structures manufactured by selective laser melting (SLM). International Journal of Advanced Manufacturing Technology. 2016;84(58):1391-1411.
32. Wu T, Liu BT, Liu JH. Study on nickel-based superalloy selective laser melting process parameters. Journal of Heilongiiang University of Science \& Technology. 2015;25(4):361-365.

33. Wang ZE, Guan K, Gao M, Li XY, Chen XF, Zeng XY. The microstructure and mechanical properties of deposited-IN718 by selective laser melting. Journal of Alloys and Compounds. 2012;513:518-523.

34. Ferrar B, Mullen L, Jones E, Stamp R, Sutcliffe CJ. Gas flow effects on selective laser melting (SLM) manufacturing performance. Journal of Materials Processing Technology. 2012;212(2):355-364.

35. Liu BT, Liu QL, Du S, Zou B, Yan W, Liu JH, et al. Preparation and Properties of IN718 Nickel-base High Temperature Alloy by Selective Laser Melting Forming. Heat Treatment Technology and Equipment. 2015,25(4):361-365.

36. Amato KN, Gaytan SM, Murr LE, Martinez E, Shindo PW, Hernandez J, et al. Microstructures and mechanical behavior of Inconel 718 fabricated by selective laser melting. Acta Materialia. 2012;60(5):2229-2239.

37. Xia MJ, Gu DD, Yu Q, Dai DH, Chen HY, Shi QM. Selective laser melting 3D printing of Ni-based superalloy: understanding thermodynamic mechanisms. Science Bulletin. 2016;61:1013-1022.

38. Feng KY, Liu P, Li HX, Sun SY, Xu SB, Li JN. Microstructure and phase transformation on the surface of Inconel 718 alloys fabricated by SLM under $1050^{\circ} \mathrm{C}$ solid solution + double ageing. Vacuum. 2017;145:112-115.

39. Yu WY, Lu WJ, Xia TD. Formation Process of Joints Brazing with Amorphous Filler Metal. Rare Metal Materials and Engineering. 2013;42(4):688-691.

40. Sun LL, Pang SJ, Liu Y, Xiong HP, Zhang T. A Ti-Zr-Cu-NiCo-Fe-Al-Sn amorphous filler metal for improving the strength of Ti-6Al-4V alloy brazing joint. Progress in Natural Science: Materials International. 2017;27(6):687-694.

41. Nieroda J, Rybak A, Kmita G, Sitarz M. Investigation of the influence of pretreatment parameters on the surface characteristics of amorphous metal for use in power industry. Journal of Molecular Structure. 2018;1160:360-367.

42. Xia CZ, Wu L, Xu XP, Zou JS. Phase constitution and fracture analysis of vacuum brazed joint of 50Mo-50Re refractory alloys. Vacuum. 2017;136:97-100

43. Wu XW, Chandel RS, Li H, Seow HP, Wu SC. Induction brazing of Inconel 718 to Inconel X-750 using Ni-Cr-Si-B amorphous foil. Journal of Materials Processing Technology. 2000;104(1-2):34-43.

44. Ma QS, Li YJ, Wu N, Wang J. Microstructure of Vacuum-Brazed Joints of Super-Ni/NiCr Laminated Composite Using Nickel-Based Amorphous Filler Metal. Journal of Materials Engineering and Performance. 2013;22(6):1660-1665.

45. Massalski TB, ed. Binary Alloy Phase Diagrams. Materials Park: ASM International; 1986. 